\title{
HTLV-1キャリアー血清中のプリン代謝酵素
}

\author{
坪井 泉 ${ }^{1)}$ 新宮 世三2) 横山 三男 ${ }^{1)}$ \\ 1) 久留米大学医学部免疫学講座 \\ 2) 宮崎県立日南病院小児科
}

（昭和63年 3 月 9 日受付）

\section{PURINE METABOLIC ENZYMES IN SERA OF HEALTHY HTLV-1 CARRIERS}

\author{
Izumi Tsuboi*, Toshimitsu Shingu** and Mitchel M. Yokoyama* \\ *Department of Immunology, Kurume University School of Medicine \\ **Nichinan Hospital, Miyazaki
}

The purine metabolic enzymes; adenosine deaminase (ADA) and purine nucleoside phosphorylase (PNP) are known to be associated with lymphocyte differentiation. ADA isoenzyme (ADA1 and ADA2) and PNP activities were assayed in the sera of 22 healthy carriers with positive for anti-HTLV-1 antibody and 20 normal individuals. The results revealed that both ADA2 and PNP activities were significantly elevated in sera of healthy carriers $(p<0.001)$ as compared with normal controls. No significant difference in ADA1 activity was noted in the two groups. These data imply that ADA2 serum level is more likely to reflect the condition of peripheral T lymphocytes than that of total ADA activity. Measurement of these enzyme activities in serum may be a useful parameter of diagnosis in human T-cell leukemia/lymphoma virus-1 infection.

\section{序 \\ アデノシンデアミナーゼ（EC 3•5・4・4；ADA）} とプリンヌクレオシドホスホリラーゼ (EC 2・4・ $2 ・ 1 ； \mathrm{PNP})$ は，プリン代謝経路に関与する酵素 である。そして，これらの両酵素は生体組織に広 く分布しているが1), 特に肝, 脾, 胸腺などのリン パ系組織に多く存在している。

Giblett't施，赤血球の ADA 欠損による重症 複合型の免疫不全症, さらに, PNP 欠損による細 胞性免疫不全症との関連を報告3) して以来, 両酵 素の免疫系との関係が注目されるようになった。

ADA は，分子量ならびに動力学的に多様性を 示すことが知られており，分子量 35,000 ダルトン の $\mathrm{ADA} 1$ と 100,000 ダルトンの ADA 活性を持た ない蛋白 (combining protein; $\mathrm{cp}$ ) とADA1が 各々 2 分子結合した複合体 $(280,000$ ダルトン)の $\mathrm{ADA} 1+\mathrm{cp}$ ，ならびに 100,000 ダルトンの ADA2 の存在が知られている4).

HTLV-1感染による成人 T 細胞白血病 (ATL)

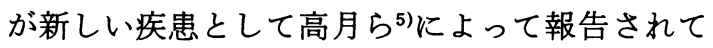

以来, 現在までに多くの患者が本邦西南の海岸地 域で発生している.我々は, この ATL 患者血清中 の ADA 活性が高値を示すことを報告した ${ }^{6)}$. 今 回，HTLV-1キャリアー血清中の ADA アイソザ イムとして酵素活性の特異性の異なる ADA1お よびADA2ならびに PNP の活性を測定し, HTLV-1感染との関係について検討したので報告 する.

\section{対象および方法}

\section{1. 試薬}

Erythro-9-(2-hydroxy-3-nonyl) adenine （EHNA）はマルホ株式会社大淀研究所より提供 された.ミルク由来のキサンチンオキシダーゼ(バ イオザイム社）扣よびウシの肝由来のグルタミン 酸デヒドロゲナーゼ（ジェンザイム社）は和光純 薬より購入した。他の試薬類は特級もしくはこれ に準ずる級品を使用した。

2. 対象

日南病院での外来患者扣よび集団検診より得た キャリアー（ATL 関連抗体陽性者）22例および健 
常人 20 例の血清を用いた。

\section{3. 測定方法}

ADA アイソザイムの測定：ADA 総活性值は, 日立705型オートアナライザーを用いて測定した。 アデノシン $6 \mathrm{mM}, \alpha$-ケトグルタル酸ナトリウム $1.1 \mathrm{mM}, \mathrm{NADH} 0.26 \mathrm{mM}$, グルタミン酸デヒド ロゲナーゼ $50 \mathrm{U} / \mathrm{ml}$ および $0.1 \mathrm{M}$ トリスマレイン 酸緩衝液（pH 7.3）を含む基質緩衝液 $360 \mu 1$ に試

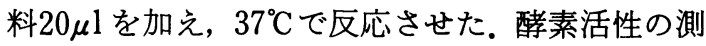
定は, 波長340および376nm の二波長で， 4 分より 9 分までの吸光度の変化より，1 分間当りの $\mathrm{NADH}$ の減少量を求め, アデノシンょり生成し たイノシン量を算出した。ADA2の活性値は, Ratech $5^{7)}$ の方法に基づき，基質緩衝液に EHNA 0.1mM を添加し, ADA1扣よび ADA1+ $\mathrm{cp}$ の活性を選択的に阻害することにより，残った ADA2の活性を測定した。ADA1活性は総活性よ り $\mathrm{ADA} 2$ 活性を差し引くことにより求めた。活性 単位は, 1 分間に $1 \mu \mathrm{mol}$ のイノシンを生成する活 性を1Uとした。

PNP の測定：PNP 活性は, 日立705型オート アナライザーを用いて，イノシン $0.5 \mathrm{mM}$ ，ニトロ ブルーテトラゾリウム $0.24 \mathrm{mM}, 1$-メトキシフェ ナジンメトサルフェート $0.028 \mathrm{mM}$, キサンチンオ キシダーゼ $0.13 \mathrm{U} / \mathrm{ml}$ および $0.1 \mathrm{M}$ 燐酸塩緩衝液 （pH7.0）を含む基質緩衝液 $360 \mu 1$ に試料 $20 \mu 1$ を加 え， $37^{\circ} \mathrm{C}$ で反応させた。測定波長 546 和よび700nm の二波長で， 4 分より 9 分までの吸光度の変化よ り, 予め求めたヒポキサンチンの吸光係数に基づ き，イノシンょり 1 分間に生成したヒポキサンチ ン量を算出した。活性単位は 1 分間に $1 \mu \mathrm{mol}$ のヒ ポキサンチンを生成する活性を1U とした。

\section{4. 有意差の検定法}

有意差については, Student's t 検定を用いて 行った.

\section{成 續}

1. 健常人の $\mathrm{ADA}$ アイソザイムと PNP 活性 値

健常人の血清についての ADA1，ADA2および PNP 活性値の分布を図 1 に示した。健常人の血 清各酵素に対する平均値士標準偏差は, ADA1：

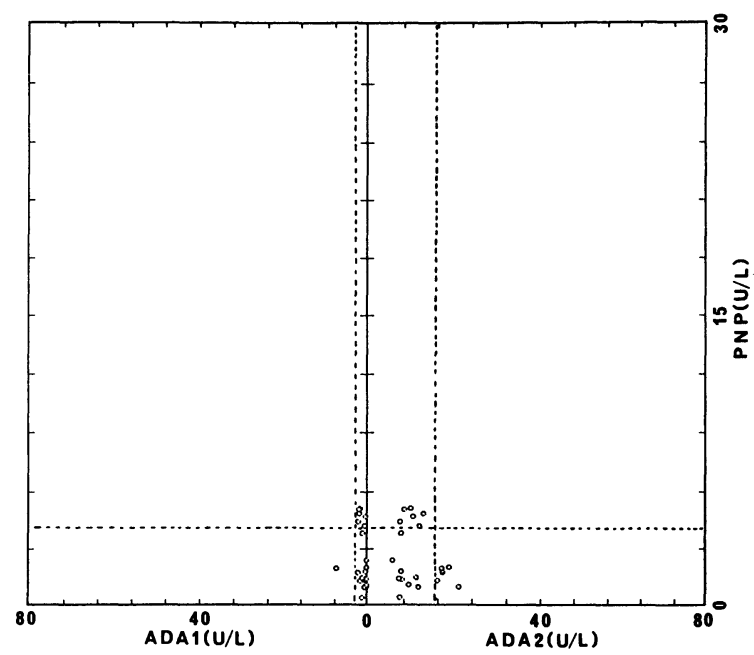

図 1 健常人の血清中の ADA アイソザイムと PNP 活性値の分布〔図中の破線は, 健常人の各酵素に対 する平均値 $+\mathrm{SD}(\mathrm{U} / \mathrm{L})$ を示す

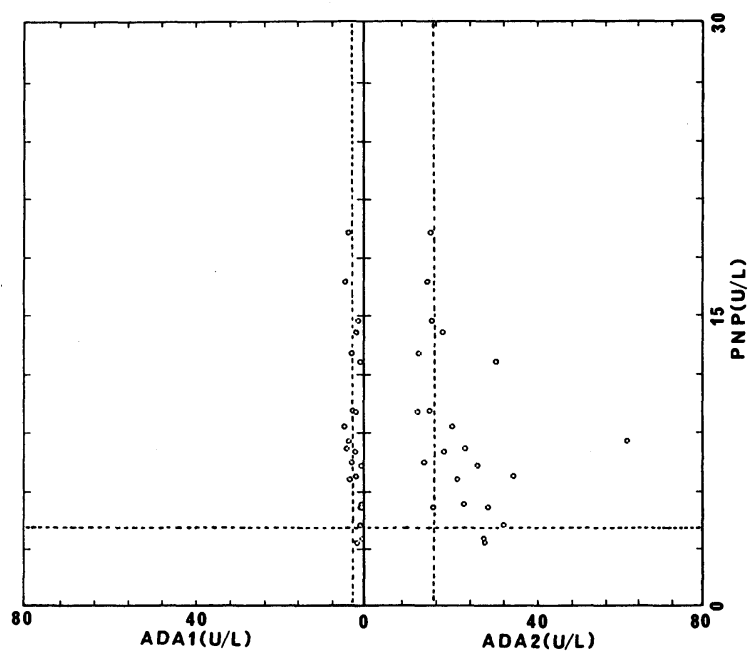

図 2 HTLV-1キャリアー血清中の ADA アイソザイ ムと PNP 活性值の分布〔図中の破線は, 健常人の各 酵素に対する平均値 $+\mathrm{SD}(\mathrm{U} / \mathrm{L})$ を示す]

$1.1 \pm 1.5(\mathrm{U} / \mathrm{L})$, ADA2 $: 11.7 \pm 4.4(\mathrm{U} / \mathrm{L})$, PNP : $2.4 \pm 1.6(\mathrm{U} / \mathrm{L})$ であった.

2. キャリアーの ADA アイソザイムと PNP 活性值

キャリアーの血清 ADA1, ADA2执よび PNP 活性值の分布を図 2 に示した。キャリアーの ADA2拈よびPNPの酵素活性值は，それぞれ 
表 1 HTLV-1キャリアー血清中の ADA アイソザ イムと PNP 活性値

\begin{tabular}{|c|c|c|c|c|}
\hline & 項目 & 例 数 & 平均 $\pm \mathrm{SD}$ & $\mathrm{t}$ 検定 \\
\hline \multirow{3}{*}{ 健 常 人 } & ADA1 & 20 & $1.1 \pm 1.5$ & \\
\hline & ADA2 & 20 & $11.7 \pm 4.4$ & \\
\hline & PNP & 20 & $2.4 \pm 1.6$ & \\
\hline \multirow{3}{*}{$\begin{array}{l}\text { HTLV-1 } \\
\text { キャリアー }\end{array}$} & ADA1 & 22 & $1.9 \pm 1.3$ & - \\
\hline & ADA2 & 22 & $23.4 \pm 11.0$ & $*$ \\
\hline & PNP & 22 & $8.9 \pm 4.3$ & $*$ \\
\hline
\end{tabular}

一：有意差なし $*$ : p $<0.001$

$23.4 \pm 11.0,8.9 \pm 4.3$ であり，健常人に比べて有

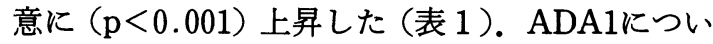
ては, キャリアーと健常人の有意差は認められな かった.

今回の分析より，HTLV-1キャリアーでは ADA2扎よび PNP の有意な上昇が見られた。

\section{考察}

Van Laarhoven ら ${ }^{8)}$ は, Tリンパ球の ADA お。 よび PNP の活性が胸腺細胞の分化段階に応じて 変動することを報告している，すなわち，未熟な T リンパ球では ADA が高く，細胞が成熟するの に従って順次低下する。これに対して，PNPは， 細胞が成熟するにつれて上昇するという特徴があ る.

ATL 患者の末梢血より得られた ATL 細胞の 膜表面抗原は, $\mathrm{CD}^{+}, \mathrm{CD}^{+}, \mathrm{CD}^{-}, \mathrm{Tac}^{+}$で, 活 性化したヘルパー/インデューサーT 細胞の形質 を表現している9).HTLV-1キャリアーでも, $\mathrm{Tac}^{+}$ の活性化した $\mathrm{T}$ リンパ球の陽性率が健常人に比 べてわずかに上昇しており，この細胞を培養する と陽性率が増加することが報告闪されている。 た, $\mathrm{T}$ 細胞由来の急性リンパ性白血病のリンパ球 では, ADA 活性が高値を示し ${ }^{11)}, \mathrm{T}$ 細胞が活性化 した他の疾患でも ADA 活性が上昇するといら報 告がある12). このことは, ATL やキャリアーでは Tリンパ球が活性化した形質を持つことから, 細 胞内の ADA 活性は元進していると考えられる。 それゆ光, ATL やキャリアー血清中の ADA 活性 の上昇は, HTLV-1感染に由来すると推察される。 血清中.の ADA アイソザイムと各疾患との関連
性については，肝疾患で検討されている，すなわ ち，急性の肝細胞障害を抗こす HB 肝炎，八口セン肝炎などでは, ADA1が上昇するのに対し, 慢 性肝炎, 肝硬変, 肝癌などでは, ADA2が上昇する と報告されている13)しかし，ADA アイソザイム とリンパ系疾患との関連性については, 現在まで に報告がない。

ATL 患者血清中の ADA アイソザイムと PNP 活性を測定した結果 ${ }^{14)}$ からキャリアーに比べて 慢性型，急性型の ATLへと病態が進行するに 伴って, ADA2および PNP 活性が高值を示した。 このことから, ADA2活性の上昇は, HTLV-1感染 による慢性化の程度を表していると考えられた。

一方, 血清中の PNP 活性値と疾患についての 報告は少なく, 急性リンパ性白血病で軽度の上昇 がみられる(15) と報告されているのみであり，今回 の血清 PNP 活性の上昇は, ATL の病態による変 動と考えられた。

\section{結 語}

血清あるいは血浆中のプリン代謝酵素を測定す ることにより, HTLV-1に感染したキャリアーで はADA アイソザイムである ADA2および PNP 活性が上昇することが判明したことから，これら の酵素活性值を測定することにより, HTLV-1 感 染のマーカーになると考えられた。

\section{文 献}

1) Ma, D.D.F., Sylwestrowica, T.A., Granger, S., Massaia, M., Franks, R., Janossy, G. and Hoffbrand, A.V.: Distribution of terminaldeoxynucleotidyl transferase and purine degradative and synthetic enzyme in subpupulation of human thymocytes. J. Immunol., 129 : 1430-1435, 1982.

2) Giblett, E.R., Anderson, J.E., Cohen, F., Pollara, B. and Meuwissen, H.J. : Adenosinedeaminase deficiency in two patients with serverly impaired cellular immunity. Lancet, ii : 1067-1069, 1972.

3) Giblett, E.R., Ammann, A.J., Wara, D.W., Sandman, R. and Diamond, L.K. : Nucleoside phosphorylase deficiency in a child with serverly deficient T-cell immunity and normal B-cell immunity. Lancet, i : 1010-1013, 1975.

4) Hirschhorn, R. and Ratech, H.: Isozymes of adenosine deaminase. In Isozymes. Alan R. Liss 
Inc., New York, 4: 131-157, 1980.

5) Takatsuki, K., Uchiyama, T., Sagawa, K. and Yodoi, J.: Topics in hematology (edite by Seno, S., Takaku, F. \& Irino, S.), Excerpta Medica, Amsterdam, 1977.

6）横山三男, 坪井 泉: AIDS ならびに ATL 患者 血清中の核酸代謝系の酵素活性値. 臨床免疫, 20 ： 114-116, 1988.

7) Ratech, H., Thorbecke, G.J., Meredith, G. and Hirschhorn, R.: Compairson and possible homology of isozymes in aves and humans. Enzyme, 26: 74-84, 1981.

8) Van Laarhoven, J.P.R.M., Spierenbur, G.T., Collet, H., Delespesse, G. and De Bruyn, C.H.M. M. : Purine interconversion pathways in T, B, $\mathrm{T} \gamma$ and $\mathrm{T}-\mathrm{T} \gamma$ cells from human peripheral blood. Adv. Exp. Med. Biol., 165 : 111-118, 1984.

9) Hattori, T., Uchiyama, T., Toibana, T., Takatsuki, K. and Uchino, H.: Surface phenotype of Japanese adult T-cell leukemia cells characterized by monoclonal antibodies. Blood, 58 :
645-647, 1981.

10) Yasuda, K., Sei, Y., Yokoyama, M.M. and Tanaka, K.: Healthy HTLV-1 carriers in Japan: The haemotological and immunological characteristicus. Br. J. Haematol., $64:$ 195-203, 1986.

11) Van Laarhoven, J.P.R.M. and De Buryn, C.H. M.M.: Purine metabolism in relation to leukemia and lymphoid cell differentiation. Leuk. Res., $7:$ 451-480, 1983.

12）森崎隆幸, 藤井寿一, 三輪史朗：白血病における 血墏アデノシンデアミナーゼ (ADA) 活性の臨床 的意義. 臨床血液, $26: 1768-1773,1985$.

13）倉田矩正, 鬼原道夫：血清 Adenosine deaminase 活性と分子多様性. 臨床病理, 32：875-880, 1984.

14）坪井 泉, 村岡俊春, 新里 脩, 荒木弘一, 横山 三男：ATL患者ならびにキャリアー血清中のプ リン代謝酵素. 臨床免疫, $20 ： 487-493,1988$.

15）磯野倫夫, 沢木春二：種々の疾患における血清 adenosine deaminase, purine nucleoside phosphorylase の変動. 医学と生物学, $111: 43-46$, 1985. 